\title{
Glucose Sensing Using Glucose Oxidase-Glutaraldehyde- Cysteine Modified Gold Electrode
}

\author{
J. Lović ${ }^{1}$, S. Stevanović ${ }^{1}$, N.D. Nikolić ${ }^{1}$, S. Petrovic ${ }^{2}$, D. Vukovic ${ }^{3}$, N. Prlainovic ${ }^{4}$, \\ D. Mijin ${ }^{2}$ and M. Avramov Ivic ${ }^{1, *}$ \\ ${ }^{1}$ ICTM - Institute of Electrochemistry, University of Belgrade, Njegoševa 12, 11000 Belgrade, Serbia \\ ${ }^{2}$ Faculty of Technology and Metallurgy, University of Belgrade, Karnegijeva 4, 11000 Belgrade, \\ Serbia \\ ${ }^{3}$ Faculty of Medicine, University of Belgrade, Dr Subotića 8, 11000 Belgrade, Serbia \\ ${ }^{4}$ Innovation Center of Faculty of Technology and Metallurgy, University of Belgrade, Karnegijeva 4, \\ 11000 Belgrade, Serbia \\ *E-mail: milka@tmf.bg.ac.rs
}

doi: $10.20964 / 2017.07 .65$

Received: 24 April 2017 / Accepted: 12 May 2017 / Published: 12 June 2017

The method to develop a stable glucose biosensor with successive attachment of cysteine (Cys), glutaraldehyde (GA) and glucose oxidase (GOx) onto gold electrode is presented. The cyclic voltammetry $(\mathrm{CV})$ suggests the diffusion control of the glucose oxidation. The obtained biosensor shows a fast electron transfer of $k^{0}=20.4 \mathrm{~s}^{-1}$, high affinity for glucose with the apparent MichaelisMenten constant $K_{M}^{a p p}=1.15 \mathrm{mM}$, a low detection limit of $0.94 \mathrm{mM}$ in a linear range $1.5-7 \mathrm{mM}$. This biosensor exhibits good stability and reproducibility. Good biocompatibility of modified electrode surface, which enhances the covalent bonded enzyme and consequently glucose oxidation, resulted in biosensor with excellent performances. Biosensor was tested in samples containing human serum.

Keywords: Biosensors; Immobilization; Enzyme catalysis; Self-assembly.

\section{FULL TEXT}

(C) 2017 The Authors. Published by ESG (www.electrochemsci.org). This article is an open access article distributed under the terms and conditions of the Creative Commons Attribution license (http://creativecommons.org/licenses/by/4.0/). 